\title{
Oviposition Preference of the Mimosa Webworm, Homadaula anisocentra (Lepidoptera: Plutellidae) ${ }^{1}$
}

\author{
ROBERT C. NORTH² AND E. R. HART \\ Department of Entomology, lowa State University, Ames, lowa S001I
}

\begin{abstract}
Environ. Entomol. 12: 546-55! (1983)
ABSTRACT In the field, the mimosa webworm, Homadaula anisocentra Meyrick (Lepidoptera: Plutellidae), oviposits preferentially on branches or on leaf rachises or petioles of uninfested omamental honeylocust, Gleditsia triacanthos L. On infested trees, oviposition occurs almost entirely on larval webbing. In the laboratory, uninfested mature leaves of both honeylocust and mimosa, Albizzia julibrissin Durazzini, are preferred over uninfested young leaves as oviposition sites. The addition of larval webbing to leaves of any age or to nonhost substrate induces oviposition preferentially on the webbing.
\end{abstract}

The mimosa webworm, Homadaula anisocentra Meyrick, a native of southeast Asia, first was recorded in the United States in 1940 (Clarke 1943). It was found feeding on ornamental mimosa, Albizzia julibrissin Durazzini, in Washington, D.C. Webster and St. George (1947) were the first to report the mimosa webworm feeding on ornamental honeylocust, Gleditsia triacanthos $\mathrm{L}$. The insect has expanded its range throughout the eastern states and has been introduced into California (Heppner and Dekle 1975, Furniss and Carolin 1977), becoming a serious pest of ornamental honeylocust, as well as mimosa. The extensive planting of $G$. triacanthos varieties during and after the decline of the American elm has hastened the range expansion of the insect. Although still considered a highly desirable urban tree, cultivars of ornamental honeylocust have been removed from many recommended and approved planting lists as a result of the susceptibility to defoliation by the mimosa webworm.

This species overwinters in the pupal stage and emerges and mates in late spring. The eggs are deposited on leaves and flowers of the mimosa tree (Clarke 1943, Webster and St. George 1947) and on the leaflets, rachises, petioles, and on the bark of small branches and twigs of the honeylocust (McManus 1962, Zewadski 1976). Second-generation and later-emerging first-generation females are reported to oviposit as well on the conspicuous larval webbing (McManus 1962, Galford and Peacock 1968, Schuder 1976). These reports have been based upon scattered observations. No studies have attempted to define the actual effects of foliage presence or age, to quantify the effects of webbing upon oviposition behavior, or to relate such effects to probability of attack.

The objectives of the study reported here were to: (1) define quantitatively the preferred oviposition sites; (2) determine the relationship between oviposition site preference and larval webbing; and (3) describe the oviposition behavior of the mimosa webworm.

\section{Materials and Methods}

Larvae and pupae were collected as needed from in-

'Received for publication 4 May 1982 . Joumal paper no. J-10608 of the Iowa Agric. Home Econ. Experiment Station, Ames. Project no. 2379.

${ }^{2}$ Present address: Dept. of Entomology, New York State Agricultural Expcriment Station, Geneva, NY 14456. fested honeylocust trees in the summer and fall of 1978 , 1979, and 1980. Larvae were placed on $G$. triacanthos seedlings in rearing cages in a greenhouse. The seedlings were grown from seeds supplied by F. W. Schumacher Co., Sandwich, Mass. Fresh seedlings were placed in rearing cages as needed. Pupae collected from the field or laboratory colony were sexed by the method proposed by Miller and Triplehorn (1979), then placed individually in $1-\mathrm{oz}$ (ca. $30-\mathrm{ml}$ ) clear plastic creamers (Bio-Serve Inc., Frenchtown, N.J.). A cotton dental wick fixed through the cap into a permanent water supply maintained humidity for the developing pupae and moisture for the adults after emergence. Each day at $1200 \mathrm{~h}$ and at $2100 \mathrm{~h}$, moths that had emerged were sexed and paired. Female moths found in copula between $0600 \mathrm{~h}$ and $0630 \mathrm{~h}$ were assumed to be gravid and were used in the oviposition experiments. A long-day regime, LD $16: 8$, was maintained in both the environmental chambers and the greenhouse. Temperatures fluctuated between 16 nd $27^{\circ} \mathrm{C}$ within the environmental chambers, night and day, respectively. Temperatures ranged from 16 to $20^{\circ} \mathrm{C}$ during the night, and from 30 to $35^{\circ} \mathrm{C}$ during the day within the greenhouse.

In 1978, 2-year-old, 2.0- to 2.5-m G. triacanthos 'Shademaster' and 'Sunburst' varieties, were obtained from Inter-State Nurseries, Hamburg, Iowa. Albizzia julibrissin rosea trees were grown from seeds obtained from F. W. Schumacher Co., Sandwich, Mass. The mimosa trees were 10 months old at the beginning of the experimental period in 1979. The trees were maintained in the insectary greenhouse under a photoperiod of LD 16:8 cycle. The date of a leaf's appearance (shortly after bud break) was recorded on a tree tag fastened next to the leaf. Older leaves were removed periodically to stimulate the growth of new leaves. For purposes of the experiments, a leaflet was designated young if it was yellow to light green and within $10 \mathrm{~cm}$ of the tip of the branch. A leaflet was considered to be mature if it was dark green, had a thick waxy cuticle, and was $10 \mathrm{~cm}$ or farther from the tip of a branch.

In 1979,28 circular screen cages $(26 \mathrm{~cm}$ in diameter by $6.5 \mathrm{~cm}$ deep) were constructed for the investigation of oviposition preferences of gravid female mimosa webworm. Twenty-eight holes, $26 \mathrm{~cm}$ in diameter, were cut through a sheet of plywood (122 by 244 by $1.3 \mathrm{~cm}$ ) in a 7 by 4 pattern. One surface of the plywood was 
then covered with wire screen. Four holes, large enough for a florist's Aquapic (Syndicate Sales Inc., Kokomo, Ind.) but too small to allow the Aquapic cap to pass through, were cut into each circular screen area in a 12$\mathrm{cm}^{2}$ pattern. A circular screcn cage was placed into each hole in the plywood sheet. In 1980, a nylon-mesh-overwire-frame cage was used to enclose the 3-year-old honeylocust trees.

Several sets of laboratory and greenhouse experiments were designed to meet objectives 1 and 2 . Experiment 1 was designed to define the preferred ovipositional sites on the tree, both with and without webbing present, and to describe any differences in ovipositional preference between two major cultivars of honeylocust (Shademaster and Sunburst). Leaf age was determined by the method described. The trees were 1.5 to $2.0 \mathrm{~m}$ tall, with a caliper of 3 to $4 \mathrm{~cm}$. Four 4 th-instar larvae were placed on the trees used in this experiment. They were allowed to feed and web for 1 day preceding removal and before the introduction of 10 gravid females.

Experiments 2 and 3 were designed to define the interactions of larval webbing and leaf age. Ten treatments were selected for the initial screening, experiment 2 , in 1979. Leaves of the appropriate age, young or mature, were removed from honeylocust and mimosa trees. The base of each petiole was sliced with a razor blade to expose fresh conductive tissue and was placed into a florist's Aquapic (treatments 1 through 4). Leaves with larval silk, frass, and feeding injury (treatments 5 and 6) were produced by placing a 4th- or 5th-instar larva on the leaf for $24 \mathrm{~h}$, the larva then being removed. Treatment 7 consisted of a wooden dowel, $20 \mathrm{~cm}$ in length, $0.3 \mathrm{~cm}$ in diameter, placed into a dry florist's Aquapic. Dowels were wrapped with larval silk by dropping a 4th- or 5th-instar larva from a height to induce it to spin a silk thread. For each application, 200 turns of the silk were wrapped around the dowel while the larva dangled at the end (treatment 8 ). Treatment 9 consisted of a silk wrap plus frass obtained from larvae crawling across a fine-mesh screen. Ten fecal pellets were collected with forceps and added to the silk wrap. A young (less than 2-week-old) honeylocust leaflet was added to a dowel wrapped with silk to produce treatment 10. Different treatments were not prepared at the same time, and all utensils were rinsed with hexane and distilled water before and between treatment preparation if they were used more than once.

Similar treatments were utilized for experiment 3 in 1980. Leaves were prepared as in 1979 from the now 3-year-old honeylocust and 2-year-old mimosa trees. Treatments 1 through 4 and treatments 11 and 12 were prepared as in 1979. Treatments 13 through 16 consisted of a wooden applicator, $15 \mathrm{~cm}$ in length, with a slit at one end to hold a piece of filter paper (Whatman no. 1, $4.5 \mathrm{~cm}$ ) on edge. Twenty turns of larval silk were wrapped around the filter paper. The filter paper was placed onto the applicator with the silk wrap parallel with the cage floor.

Four combinations of the 10 treatments were selected for testing in 1979 and 1980. Each combination was duplicated in each of seven cages during each of the four replications in 1979 and the three replications in 1980. Each of the seven cages of each combination was assigned randomly to one of the 28 positions in the 7 . by-4 pattern cut from the plywood sheet. The four treatments within each cage were randomized. One adult female mimosa webworm was placed into each cage the morning of day 1 of each replication. The females were 3 to 5 days old, and 2 days postmating. Water was supplied from a cotton dental wick fitted through the cap of a plastic creamer cup. The treatments were placed into the cages before introduction of the females. The number of eggs found on each treatment for the following six mornings was recorded. In experiment 2 (1979), the eggs were allowed to accumulate; in experiment 3 (1980), the eggs were removed daily.

A search was conducted in the spring and summer of 1981 to locate the oviposition sites used by the overwintering and first-generation adults. Four areas were searched, two in the city of Ames, lowa, one on the lowa State University campus, and one at the state fairgrounds in Des Moines. To define the ovipositional preference of females that are active before larval activity, eggs were recorded if they were present before webbing appeared. On the lowa State campus, 25 trees, representing a number of commercial varieties, were searched daily from 9 through 25 June 1981. Twenty trees were searched on $10,12,16$, and 19 June at the area designated Ames no. 1. Ten trees were searched on 23 and 26 June 1981 at the area designated Ames no. 2. Ten trees were searched on 11 and 19 June 1981 at the fairgrounds in Des Moines. All branches that were within reach $(3 \mathrm{~m})$ of a wire hook were searched. The boles of various trees were examined for eggs, and when it was possible to climb into the canopy, the bole, branches, and leaves were searched to a height of 5 to $10 \mathrm{~m}$. Eggs not in contact with webbing were found in seven locations: branch, petiole, rachis, on the top or bottom of a young leaflet, or on the top or bottom of a mature leaflet.

Once webbing was discovered in the trees, another search was conducted to define the effects of this additional parameter. Ten trees on the lowa State campus were searched on 23 and 30 July 1981, as well as on 2, 4,7 , and 10 August 1981 . Ten trees were searched at the state fairground in Des Moines on 31 July and 6 August 1981. On 26 and 27 June 1981, a count was made of eggs found on webs on 15 trees in Ames, 10 on the lowa State campus, and 5 in Des Moines. In addition to a search of the branches and leaves, ten webs were searched on each tree.

\section{Results and Discussion}

In experiment 1 , in the absence of webbing, the petiole was preferred over the rachis and the rachis was preferred over the branch and leaflets $(\mathrm{F}=22.5, P \leqslant$ 0.01 ) (Table 1). More eggs were laid on mature leaflets than on young, the difference being significant between the dorsal surface of mature leaflets and both surfaces of young leaflets. There was no significant difference between or within the two varieties. A female laid an average of 1.2 eggs per day. When trees with larval 
Table 1.-Eggs oviposited by four female mimosa webworms per honeylocust tree over a 4-day period, experiment 1

\begin{tabular}{lcc}
\hline Location & $\begin{array}{c}\text { Tree without } \\
\text { webbing }(\overline{\mathrm{x}})^{a, c}\end{array}$ & $\begin{array}{c}\text { Tree with } \\
\text { webbing }(\overline{\mathrm{x}})^{b, r}\end{array}$ \\
\hline & & \\
Branch & $2.1 \mathrm{~cd}$ & $0.5 \mathrm{~b}$ \\
Rachis & $7.0 \mathrm{~b}$ & $0.8 \mathrm{~b}$ \\
Petiole & $11.1 \mathrm{a}$ & $1.0 \mathrm{~b}$ \\
Mature leaflet & & \\
Dorsal surface & $2.6 \mathrm{c}$ & $0.3 \mathrm{~b}$ \\
Ventral surface & $1.3 \mathrm{~cd}$ & $0.0 \mathrm{~b}$ \\
Young leaflete & & \\
Dorsal surface & $0.9 \mathrm{~d}$ & $0.0 \mathrm{~b}$ \\
Ventral surface & $0.8 \mathrm{~d}$ & $0.3 \mathrm{~b}$ \\
Fresh webbing & & $154.5 \mathrm{a}$ \\
& & \\
\hline
\end{tabular}

${ }^{a} n=9$ trees

$b_{n}=4$ trees.

'Means in the same column with the same letter are not significantly different, $P \leq 0.05$, Duncan's multiple range test.

dOver 2 weeks old.

'Less than 2 weeks old

webbing were used, eggs were laid preferentially on the webbing (Table 1$)(\mathrm{F}=72.9, P \leqslant 0.01)$. There was no significant difference between or within varieties, and a female laid an average of 7.9 eggs per day.

The variety 'Sunburst' has been implicated as being more susceptible to attack, or more heavily damaged, by the mimosa webworm (McManus 1962, Schuder 1976). Preliminary studies (unpublished data) had suggested that certain directional aspects of honeylocust trees are infested preferentially. Although there was no significant difference between the varieties in experiment 1 , more eggs were oviposited on 'Sunburst' $(\bar{x}=27$ eggs per tree) than on 'Shademaster' ( $\bar{x}=21$ eggs per tree). In urban areas, the females of the overwintering generation may be attracted preferentially to 'Sunburst' or stimulated to oviposit more readily on that variety because of a chemical(s) associated with the foliage. As soon as the larvae hatch and begin to feed and web, females then prefer to oviposit at these sites. This results in a preferred area of attack and a damage bias at the point of the initial infestation. Differential survival of young instars on various varieties also could be contributing to "susceptibility."

There is evidence indicating chemical and physical intracrown variation among leaves (e.g., Auchmoody and Hammack 1975). Peacock (1967) observed that mimosa webworm larvae preferred older mature leaves for feeding and suggested that this may have been due to the presence of the alkaloid triacanthine acting as a feeding deterrent. Triacanthine concentrations are highest in fresh young leaves, and the concentration falls off sharply as the leaf ages. From field observations and those data of experiment 1 , it seems that the females are ovipositing preferentially on mature foliage. The time of bud break of honeylocust trees in Ames may vary from the last week of April (1981) to the first 2 weeks of May (1979, 1980). Regardless of when bud break occurs, at a minimum of 5 to 6 weeks later, adult webworms emerge after overwintering as pupae, mate, and begin to ovi- posit. Females probably are exposed to more mature than young foliage at that time.

The limited mobility of the young instars could contribute to this preference noted by Peacock (1967). Clarke (1943), McManus (1962), and we have observed 3rd or later instars moving out to the tips of branches to feed, where triacanthine would be at its highest concentrations. Although there is considerable evidence for lepidopterous tree defoliators preferring particular ages of leaves and compass points for feeding, e.g, fall webworm (Barbosa and Greenblatt 1979), the preference for larval feeding on older foliage in the mimosa webworm seems to be a result of oviposition site selection by the females of the overwintering generation.

The multiple-choice experiments were designed to determine the source of the principal stimuli influencing oviposition after a female had made contact with a substrate. In experiment 2a (Table 2), significantly more eggs were oviposited on treatments 1 and 4 than on treatments 2 and $3(F=67.7, P \leqslant 0.01)$. More eggs were oviposited on mature honeylocust than on mature mimosa leaves, but the difference was not significant. Peak oviposition was on the evening of the third day of oviposition (5 days postmating). Treatments 1 and 4 were significantly different from treatments 2 and 3 in experiment $3 \mathrm{a}(\mathrm{F}=73.8, P \leqslant 0.01)$, but were not significantly different from each other (Table 2). Peak oviposition was on the evening of day 3 ( 5 days postmating) and on day 2 (4 days postmating) for treatments 1 and 4 , respectively. The replacement of the treatments each day in experiment 3 a may have contributed to the increased oviposition in experiment $3 a(\bar{x}=17.4$ eggs per female) vs. experiment $2 \mathrm{a}(\overline{\mathrm{x}}=15.3$ eggs per female). The differences caused by age in experiments $2 \mathrm{a}$ and 3a were significant. Adult females may be stimulated to oviposit by some chemical(s) or tactile cues present in mature foliage. In nature, females are unlikely to encounter large quantities of young foliage in the spring. In July and August, much young foliage is contaminated by larval silk.

In experiment $2 b$, treatments 5 and 6 differed significantly from treatments 2 and 3 (Table 3 ) $(F=62.0, P$ $\leqslant 0.01$ ). No significant difference was found between treatments 5 and 6 . The number of eggs per day increased to a maximum the third evening after the intro-

Table 2.-Treatment means of eggs oviposited by female mimosa webworms, experiments $2 a$ and $3 a$

\begin{tabular}{lcc}
\hline \multicolumn{1}{c}{ Treatment } & $\begin{array}{c}1979 \\
\text { Treatments with eggs } \\
\text { accumulated }(\overline{\mathrm{x}})^{a, c}\end{array}$ & $\begin{array}{c}1980 \\
\text { Treatments replaced } \\
\text { daily }(\overline{\mathbf{x}})^{b . c}\end{array}$ \\
\hline & & \\
1. Mature honeylocust leaf & $8.1 \mathrm{a}$ & $9.0 \mathrm{a}$ \\
2. Young honeylocust leaf & $0.3 \mathrm{~b}$ & $0.3 \mathrm{~b}$ \\
3. Young mimosa leaf & $0.2 \mathrm{~b}$ & $0.0 \mathrm{~b}$ \\
4. Mature mimosa leaf & $6.7 \mathrm{a}$ & $8.0 \mathrm{a}$ \\
& & \\
\hline & & \\
${ }^{a} n=28$ females. & & \\
${ }^{b} n=21$ females. & \\
$c$ Means in the same column with the same letter are not significantly \\
different, $P \leqslant 0.05$, Duncan's multiple range test.
\end{tabular}


Tabli: 3.-Treatment means of eggs oviposited by female mimosa webworms, experiments $2 b$ and $3 b$

\begin{tabular}{|c|c|c|}
\hline Treatment & $\begin{array}{l}1979 \\
\text { Treatments with eggs } \\
\text { accumulated }(\bar{x})^{a, c}\end{array}$ & $\begin{array}{c}1980 \\
\begin{array}{c}\text { Treatments replaced } \\
\text { daily }(\overline{\mathrm{x}})^{b . c}\end{array}\end{array}$ \\
\hline $\begin{array}{l}\text { 2. Young honeylocust leaf } \\
\text { 3. Young mimosa leaf } \\
\text { 5. Young honeylocust leaf, } \\
\text { fresh larval webbing } \\
\text { 6. Young mimosa leaf, } \\
\text { fresh larval webbing } \\
\text { 1. Mature honeylocust leaf } \\
\text { 4. Mature mimosa leaf } \\
\text { 11. Mature honeylocust leaf, } \\
\text { fresh larval webbing } \\
\text { 12. Mature mimosa leaf, } \\
\text { fresh larval webbing }\end{array}$ & $\begin{array}{c}0.4 b \\
0.3 b \\
17.1 \mathrm{a} \\
17.7 \mathrm{a}\end{array}$ & $\begin{array}{r}1.1 \mathrm{~b} \\
0.3 \mathrm{~b} \\
21.9 \mathrm{a} \\
22.6 \mathrm{a}\end{array}$ \\
\hline
\end{tabular}

$a_{n}=28$ females.

${ }^{o} n=21$ females.

'Means in the same column with the same letter are not significantly different, $P \leq 0.05$, Duncan's multiple range test.

Table 4.-Treatment means of eggs oviposited by female mimosa webworms, experiments $2 c$ and $3 c$

\begin{tabular}{ccc}
\hline & 1979 & 1980 \\
Treatment & $\begin{array}{c}\text { Treatments with eggs } \\
\text { accumulated }(\bar{x})^{a . c}\end{array}$ & $\begin{array}{c}\text { Treatments replaced } \\
\text { daily }(\bar{x})^{\text {b.c }}\end{array}$ \\
& &
\end{tabular}

2. Young honeylocust leaf

$0.3 \mathrm{c}$

5. Young honeylocust leaf, fresh larval webbing $\quad 19.3$

7. Wooden dowel

8. Wooden dowel, larval silk wrap

1. Mature honeylocust leaf

11. Mature honeylocust leaf, fresh larval webbing

13. Filter paper

14. Filter paper,

laval silk wrap

$0.5 \mathrm{c}$

$7.5 b$

$0.0 \mathrm{c}$

$21.2 \mathrm{a}$

$0.0 \mathrm{c}$

$6.5 b$

$a_{n}=28$ females

$b_{n}=21$ females.

'Means in the same column with the same letter are not significantly differen*, $P \leq 0.05$, Duncan's multiple range test.

duction of the females into the cages. In experiment $3 \mathrm{~b}$, treatments 11 and 12 were significantly different from treatments 1 and 4 (Table 3$)(F=86.9, P \leqslant 0.01)$. A significant difference was found among treatments in experiment $3 \mathrm{c}$ (Table 4$)(\mathrm{F}=94.2, P \leqslant 0.01)$, as well as between treatments 11 and 14. Oviposition peaked on the third evening and second evening for treatments 5 and 8 , respectively. The time of peak oviposition occurred on the second evening after the females were placed onto the cages. In both experiments, the wraps received significantly fewer eggs than the webbing. The replacement of the treatments in experiment $3 \mathrm{c}$ did not seem to increase the number of eggs oviposited per female (experiment $2 c, \bar{x}=27.5$ eggs per female; experiment $3 c, \bar{x}=27.7$ eggs per female). The concentration of pheromone(s) on wraps could have been considerably less than on webbing. Aging may have increased the attractiveness of the leaves. This aging may have contributed to the increased oviposition on webbing over the silk wrap.

In experiments $2 \mathrm{~d}$ and $3 \mathrm{~d}$ (Table 5), there was a significant difference among treatments $(F=39.7, P \leqslant$ $0.01 ; \mathrm{F}=40.8, P \leqslant 0.01$, respectively). Treatments 8 (14), 9 (15), and 10 (16) in both experiments did not differ significantly. The treatments in experiment $3 \mathrm{~d}$ differed from those in $2 d$ in that they were replaced each day and filter paper rather than a wooden dowel was used as a substrate for the silk wrap. The number of eggs oviposited per female (experiment $2 \mathrm{~d}, \overline{\mathrm{x}}=34.6$; experiment $3 d, \bar{x}=37.2$ ) suggests that the two substrates did not differ in their effect on oviposition. There was no significant interaction among the variables frass, young honeylocust leaf, mature honeylocust leaf, and silk wrap. Contact stimuli for ovipositional site selection (in the presence of silk) rely primarily on silk, but leaf senescence, decaying frass, and decaying foliage may contribute to orientation before the antennae contact the substrate. Oviposition peaked on the evening of the second and third day after the females were placed into cages

On clear evenings, at ca. 20 min after sunset, slightly earlier for an overcast sky, moths were observed flying from daytime resting areas on shrubs and trees to the vicinity of honeylocust trees, where they fluttered around the periphery of the tree canopy. Usually, the activity was confined to rapid and direct flight at heights of a few meters above ground, but the moths were able to rise to the top of the canopy in still air. Crepuscular flight activity of adult males and females occurred regularly between $0500 \mathrm{~h}$ and $0630 \mathrm{~h}$ (CST), and between 2100 and $2330 \mathrm{~h}$, in June, July, and early August. As the season progressed into late August and September and daylength shortened, evening and morning activity maintained its synchrony with the temporal occurrence of sunset and sunrise. McManus (1962) had reported this bimodal crepuscular activity of adult mimosa web-

Table 5.-Treatment means of eggs oviposited by female mimosa webworms, experiments $2 \mathrm{~d}$ and $3 \mathrm{~d}$

\begin{tabular}{lcc}
\hline \multicolumn{1}{c}{ Treatment } & $\begin{array}{c}1979 \\
\text { Treatments with eggs } \\
\text { accumulated }(\overline{\mathrm{x}})^{\mathrm{a} . c}\end{array}$ & $\begin{array}{c}1980 \\
\text { Treatments replaced } \\
\text { daily }(\overline{\mathrm{x}})^{h, \mathrm{c}}\end{array}$ \\
\hline $\begin{array}{l}\text { 7. (13) Artificial } \\
\text { substrated }\end{array}$ & $0.2 \mathrm{~b}$ & $0.5 \mathrm{~b}$ \\
$\begin{array}{c}\text { 8. (14) Substrate, larval } \\
\text { silk wrap }\end{array}$ & $10.2 \mathrm{a}$ & $12.1 \mathrm{a}$ \\
$\begin{array}{l}\text { 9. (15) Substrate, larval silk } \\
\text { wrap, and frass }\end{array}$ & $11.3 \mathrm{a}$ & $12.7 \mathrm{a}$ \\
$\begin{array}{l}\text { 10. (16) Substrate, silk wrap } \\
\text { young honeylocust leaflet } \\
\text { (mature honeylocust } \\
\text { leaflet) }\end{array}$ & $12.9 \mathrm{a}$ & $11.9 \mathrm{a}$ \\
\hline
\end{tabular}

${ }^{a} n=28$ females

$t_{n}=21$ females.

'Means in the same column with the same letter are not significantly different, $P \leqslant 0.05$, Duncan's multiple range test.

${ }^{d} 1979=$ wooden dowel; $1980=$ filter paper. 
Table 6.-Mimosa webworm eggs found on honeylocust trees, 9 through 25 June 1981; four geographic areas

\begin{tabular}{|c|c|c|c|c|c|c|}
\hline Location & Ames no. 1 & Ames no. 2 & Campus & Des Moines & Total & $\%$ Of total \\
\hline Branch & 10 & 1 & 14 & 2 & 27 & 18 \\
\hline Mature rachis & 8 & 2 & 10 & 4 & 24 & 16 \\
\hline Mature petiole & 15 & 7 & 19 & 4 & 45 & 30 \\
\hline Young rachis & 3 & 1 & 7 & 2 & 13 & 8 \\
\hline Young petiole & 2 & 5 & 3 & 5 & I5 & 10 \\
\hline \multicolumn{7}{|l|}{ Mature leaflet } \\
\hline Dorsal surface & 4 & 3 & 6 & 0 & 13 & 8 \\
\hline Ventral surface & 2 & 2 & 1 & 1 & 6 & 4 \\
\hline \multicolumn{7}{|l|}{ Young leaflet } \\
\hline Dorsal surface & 0 & 3 & 1 & 0 & 4 & 3 \\
\hline Ventral surface & 1 & 2 & 2 & 0 & 5 & 3 \\
\hline
\end{tabular}

Table 7.-Mimosa webworm eggs associated with larval webbing found on honeylocust trees, 26 and 27 June 1981 ; four geographic areas and 10 webs per tree searched

\begin{tabular}{|c|c|c|c|c|c|}
\hline Area & No. of trees & $\begin{array}{l}\text { Uneclosed eggs on } \\
\text { bole, branches, or leaves }\end{array}$ & $\begin{array}{l}\text { Uneclosed eggs } \\
\text { on webbing }\end{array}$ & Range & Mean $\pm S D$ \\
\hline Ames no. 1 & 5 & 0 & 362 & $4-179$ & $14 \pm 8.2$ \\
\hline Ames no. 2 & 10 & 0 & 907 & $\mid-201$ & $18 \pm 6.6$ \\
\hline Campus & 10 & 0 & 1,302 & $2-219$ & $26 \pm 10.9$ \\
\hline Des Moines & 5 & 0 & 443 & $6-144$ & $16 \pm 8.5$ \\
\hline Total & 30 & 0 & 3,014 & $1-219$ & $20 \pm 10.3$ \\
\hline
\end{tabular}

worms and believed that the maximum activity observed at dusk was by ovipositing females, but was unable to observe oviposition in the field. We observed oviposition in the field between 2100 and $2300 \mathrm{~h}$ (CST), the $0500 \mathrm{~h}$ to $0630 \mathrm{~h}$ activity proving to be the mating period. From June 1979 through August 1981, 294 females were observed at night as they landed on honeylocust foliage in the field. A flashlight with a red filter was used as sparingly as possible during the observations. After landing, females walked rapidly over the surface (i.e., leaflet, petiole, rachis, or branch), making quick turning movements while examining the substrate by alternatingly or synchronously contacting the substrate with their antennae. Of the 141 females observed to contact larval webbing with their antennae, 115 stopped, curved and extended the abdomen ventrally, and deposited an egg. Occasionally (10 females), a second egg was deposited, but only after the female had moved a short distance and had contacted the substrate again with her antennae. More commonly, the moth flew from the oviposition site after placing an egg on or within the webbed leaflets. Moths observed to contact the substrate with their antennae, but that flew away without ovipositing, were captured to confirm that they were females. Twenty-six females contacted webbing with their antennae but did not oviposit. One hundred fifty-three females did not contact webbing with their antennae and did not oviposit. All oviposition observed in the field during 1979 through 1981 occurred on larval webbing where at least one larva, usually more, was present and actively feeding and webbing leaflets together.
Of the 152 first-generation eggs located during the honeylocust tree search from 9 to 25 June 1981 (Table 6 ), $82 \%$ were found on a branch, petiole, or rachis, whereas $18 \%$ were found on the leaflets. Mature foliage (70\%) was preferred over young $(30 \%)$ in the absence of larval webbing.

With the appearance of larval webbing, eggs were oviposited preferentially on the webbing (Table 7). Concentrations of from 10 to 100 eggs per web were relatively easy to locate in the field in late June to early July. No eggs were found on the bole of honeylocust trees or within the canopy that could be searched by climbing the bole. No eggs, larval webbing, or evidence of larval feeding were found on various shrubs, forbs, and trees within 5 to $20 \mathrm{~m}$ of infested honeylocust trees. In July and August (first-generation oviposition), all eggs found were associated with larval webbing at active feeding sites. Old webbing (no larval feeding at site) was void of fresh eggs.

In phytophagous insects, oviposition usually is not indiscriminate, but typically is confined to selected plant parts. The specific oviposition sites are selected in response to physical and chemical stimuli. Homadaula anisocentra, apparently by selecting oviposition sites through contact chemoreception, evidently oviposits preferentially on larval webbing when it is present. The results indicate that a pheromone is perceived by the antennae. Obviously, females also select oviposition sites in the absence of webbing (mature foliage, petiole, and rachis), and having done so, it seems that they influence the future distribution pattern of the population on the 
host tree. Communication between larvae and adult females by way of a pheromone could be both advantageous and disadvantageous. Females may discriminate quickly among suitable hosts by using the pheromone rather than host stimulants as an indicator of a suitable oviposition environment. Females would be ovipositing where food density is high and thus provide the larvae with a high probability of a rich supply of nutrients for their development. There is also the possibility of reduced predation and parasitism of larvae when the eggs are enclosed by webbing when they hatch. The Ist instars also may improve upon their nutrient uptake by feeding communally with older instars that already have removed parts of the leaf cuticle. Ephestia kuehniella females have been reported to respond to a pheromone produced by larvae by ovipositing most heavily at larval densities that are optimal for the available food (Corbet 1973). If mimosa webworm females are incapable of responding to densities that are too high for the available food, then larvae may suffer increased mortality, reduced size or developmental rate, and possibly, lower fecundity as adults. Although webbing may appear to offer protection from natural enemies, predators and parasites may respond to the kairomone, possibly reducing the protection afforded by this webbing. Females also, in responding to the stimulus provided by webbing, may select sites that contain nothing more than dead and decaying foliage and of no nutritional value to the larvae.

Hopkins' "host selection principle" assumes that female adults prefer to oviposit on hosts upon which they fed as immatures (Hopkins 1917). This preference could divide populations into isolated host-associated races, each feeding on a single species, and could provide a mechanism for sympatric speciation. This process is an attractive means of explaining rapid host shifts by phytophagous insects (e.g., Phillips and Barnes 1979). However, such larval conditioning does not necessarily influence the oviposition behavior of the adult (Wood 1963, Knerer and Atwood 1973, Wiklund 1975). The relationship among the mimosa webworm and its hosts involving tactile and chemical stimulants, deterrents (secondary compounds), the role of nutrients, and the presence of a larval-produced oviposition stimulant in the selection of feeding and ovipositional sites offers a unique opportunity to test Hopkins' hypothesis further. Chemical characterization of known hosts, Gleditsia, Albizzia, Gymnocladus, and the original host(s) from eastern Asia will need to be accomplished, and the appropriate bioassays must be used to examine larval feeding and adult oviposition.

\section{REFERENCES CITED}

Auchmoody, L. R., and K. P. Hammack. 1975. Foliar nutrient variation in four species of upland oaks. U.S. For. Serv. Res. Pap. NE-331. 16 pp.

Barbosa, P., and J. G. Greenblatt. 1979. Effects of leaf age and position on larval preferences of the fall webworm, Hyphantria cunea (Lepidoptera: Arctiidae). Can. Entomol. 111: $381-383$.

Clarke, J. F. G. 1943. A new pest of Albizzia in the District of Columbia (Lepidoptera: Glyphterygidae). Proc. U.S. Natl. Mus. 93: 205-208.

Corbet, S. A. 1973. Oviposition pheromone in larval mandibular glands of Ephestia kuehniella. Nature (London) 243: $537-538$

Furniss, R. L., and V. M. Carolin. 1977. Western forest insects. U.S. For. Serv. Mis. Publ. 1339. 654 pp.

Galford, J. R., and J. W. Peacock. 1968. Combined laboratory and greenhouse techniques for year-round rearing of the mimosa webworm, Homadaula anisocentra. Ann. Entomol. Soc. Am. 61: 919-920.

Heppner, J. B., and C. W. Dekle. 1975. Mimosa webworm, Homadaula anisocentra Meyrick (Lepidoptera: Plutellidae). Fla. Dep. Agric. Consum. Serv. Div. Plant Ind. Entomol. Circ. 157. 2 pp.

Hopkins, A. D. 1917. A discussion of C. B. Hewitt's paper "insect behavior." J. Econ. Entomol. 10: 92-93.

Knerer, G., and C. E. Atwood. 1973. Diprionid sawflies: polymorphism and speciation. Science 179: 1090-1099.

McManus, M. L. 1962. The life history of the mimosa webworm (Homadaula albizziae Clarke). M.S. thesis, Purdue University W. Lafayette, Ind. $58 \mathrm{pp}$.

Miller, M. R., and C. A. Triplehorn. 1979. Sex determination in pupae of the mimosa webworm, Homadaula anisocentra Meyrick (Lepidoptera: Glyphipterygidae). J. Kans. Entomol. Soc. 52: 420.

Peacock, J. 1967. An investigation of the chemical constituents of honeylocust, Gleditsia triacanthos L. as phagostimulants for larvae of the mimosa webworm, Homadaula albizziae Clarke. Ph.D. dissertation, The Ohio State University, Columbus. $88 \mathrm{pp}$.

Phillips, P. A., and M. M. Barnes. 1975. Host races formation among sympatric apple, walnut, and plum populations of the codling moth, Laspeyresia pomonella. Ann. Entomol. Soc. Am. 68: 1053-1060.

Schuder, D. L. 1976. Mimosa webworm. Purdue Univ. Coop. Ext. Serv. (Publ.) Ell. 2 pp.

Webster, H. V., and F. A. St. George. 1947. Life history and control of the webworm, Homadaula albizziae. J. Econ. Entomol. 40: 546-552.

Wiklund, C. 1975. The evolutionary relationships between adult oviposition preferences and larval host plant range in Papilio machaon L. Oecologia 18: 185-197.

Wood, D. L. 1963. Studies on host selection by Ips confusus (Leconte) (Coleoptera: Scolytidae). Univ. Calif. Publ. Entomol. 27: 241-282.

Zewadski, R. M. 1976. Mimosa webworm control. Ill. Nat. Hist. Surv. Rep. 157. 2 pp. 